mendations made by the Committee appointed by the Prime Minister under the chairmanship of Sir Alexander Fleck to examine the organization of certain parts of the Authority. Further appointments will be announced in due course.

Mr. D. W. Fry, chief physicist at Harwell, has been appointed a deputy director of the Atomic Energy Research Establishment and took up his new post on February 17.

\section{Prof. Heinrich Balss}

Dr. J. Théodorides of the University of Paris has written to say that, in the obituary notice of Prof. Heinrich Balss, which appeared in Nature of December 21, 1957, p. 1391, he was surprised to find no reference to Prof. Balss's important works on the medieval naturalist, Albert the Great. Dr. Isabella Gordon wishes to add that Prof. Balss's scholarly contributions to the history of biology and medicine include the following: "Albertus Magnus als Zoologe" (Munich, 1928); "Albertus Magnus als Biologe : Werk und Ursprung", Grosse Naturforscher, 1 (Stuttgart, 1947) and "Aristoteles Biologische Schriften", with Greek text and German translation (Munich, 1943).

\section{Announcements}

ThE following medal awards have been made by the Royal Astronomical Society: Gold Medal: Prof. André Danjon, for his contributions to astronomical photometry, to fundamental astronomy and to the design of astronomical instruments; Eddington Medal : Dr. H. W. Babcock, for his work on the magnetic fields of early-type stars and of the Sun.

Dr. L. A. Jordan, director of the Research Association of British Colour and Varnish Manufacturers, has been appointed professor of chemistry at the Royal Academy of Arts in succession to Dr. H. J. Plenderleith, keeper of the Research Laboratory, British Museum.

THE British Institute of Radiology has made the following awards for 1958 : the Barclay Medal to Dr. G. M. Ardran (Nuffield Institute for Medical Research, Oxford) ; the Röntgen Award to Dr. P. R. J. Burch (Department of Medical Physics, General Infirmary, Leeds); and the Barclay Prize. (posthumously) to the late Dr. Trevor Griffiths (Brook Hospital, Shooters Hill Road, London).

THE Road Research Laboratory of the Department of Scientific and Industrial Research is again holding open days, this year on May 15 and 16. The Materials and Construction Division and the Colonial Section are at Harmondsworth, Middlesex, and the Traffic and Safety Division at Langley, Buckinghamshire. The Scottish Branch of the Laboratory at Thorntonhall, near Glasgow, will be open to visitors on June 4 and 5 .

THE third International Seaweed Symposium will be held in Galway during August 13-19. Further information can be obtained from the Secretariat, Third International Seaweed Symposium, University College, Galway, Ireland. Abstracts of communications must reach the Secretariat before April 1.

A sxmposium on "The Pharmacology of Phenolic Substances" is to be held at Oxford on April 10 and 11 in conjunction with the first annual general meeting of the Plant Phenolics Group. Applications to attend should be made to the secretary, Dr. T. Swain, Low Temperature Research Laboratory, Downing Street, Cambridge.

THE Nutrition Society is holding a symposium on "Fish" in the Physiology Lecture Theatre, the Old Medical School, the University of Liverpool, during March 28-29. Further information can be obtained from the hon. programmes secretary of the Nutrition Society, Miss D. F. Hollingsworth, c/o Ministry of Agriculture, Fisheries and Food, Great Westminster House, Horseferry Road, London. S.W.1.

THE 1958 International Starch Convention, organized by the German Cereals Research Association, will be held at Detmold, West Germany, during April 22 24. The programme will include papers on research and analysis; starch fractions and derivatives; starch manufacture and practice. Further information can be obtained from Dr. Eric Dux, Sichel Adhesives, Ltd., Riverside Works, 6 Friars Lane, Richmond, Surrey.

A symposrum on "Numerical Approximation", sponsored by the Mathematics Research Center, U.S. Army, will be held during April 20-23 at the University of Wisconsin, Madison. The topics of the symposium include linear approximation, interpolation, Tchebycheff and other extremal approximations, expansions and algorithms. Further information can be obtained from Prof. R. E. Langer, Mathematics Research Center, U.S. Army, University of Wisconsin, 1118 W. Johnson Street, Madison 6, Wisconsin.

The spring conference of the X-ray Analysis Group of the Institute of Physics will be held in the College of Science and Technology, Manchester, during April 18-19. There is no specific topic, and papers will be presented on a wide range of subjects, including optical diffraction methods, structural investigations, and X-ray diffraction and X-ray spectrographic techniques. The conference is open to all interested persons on completion of an application form to be obtained from the honorary conference secretary, Dr. C. A. Taylor, Department of Physics, College of Science and Technology, Sackville Street, Manchester 1, to whom all inquiries should be addressed.

THE Silver Jubilee Symposium on "The Physical Properties of Polymers" arranged by the Plastics and Polymer Group of the Society of Chemical Industry will be devoted to the fundamental investigation of mechanical and electrical processes in polymers and the physical testing of polymers. It will be held at the William Beveridge Hall, Senate House, University of London, London, W.C.1, during April 15-17. The proceedings will be conducted under the general chairmanship of Mr. C. E. Hollis, chairman of the Group, and Dr. V. E. Yarsley, Mr. C. G. Garton and Dr. L. R. G. Treloar will take the chair for the three daily sessions. Further information can be obtained from the Assistant Secretary (Plastics and Polymer Group), Society of Chemical Industry, 14 Belgrave Square, London, S.W.1.

IN the review of "Recruitment of Skilled Trades" by Lady Williams published in Nature of February 8 , p. 373 , it is stated in the first parrgraph that questionnaires were sent to 9,000 firms. This is incorrect : in fact, 1,000 firms were approached, and 550 replied. 